\title{
Adenylate effects on protein phosphorylation in the interenvelope lumen of pea chloroplasts
}

\author{
Jürgen Soll ${ }^{1}$, Veronika Berger ${ }^{1}$, and John Bennett ${ }^{2}$ \\ ${ }^{1}$ Botanisches Institut der Universität München, Menzinger Strasse 67, D-8000 München 19, Federal Republic of Germany, and \\ ${ }^{2}$ Biology Department, Brookhaven National Laboratory, Upton, NY 11973, USA
}

\begin{abstract}
A 64-kilodalton $(\mathrm{kDa})$ protein, situated in the lumen between the inner and outer envelopes of pea (Pisum sativum L.) chloroplasts (Soll and Bennett 1988, Eur. J. Biochem., 175, 301-307) is shown to undergo reversible phosphorylation in isolated mixed envelope vesicles. It is the most conspicuously labelled protein after incubation of envelopes with $33 \mathrm{nmol} \cdot 1^{-1}\left[\gamma_{-}{ }^{32} \mathrm{P}\right]$ ATP whereas incubation with $50 \mu \mathrm{mol} \cdot 1^{-1}\left[\gamma^{-32} \mathrm{P}\right]$ ATP labels most prominently two outer envelope proteins (86 and $23 \mathrm{kDa}$ ). Half-maximum velocity for phosphorylation of the 64-kDa protein occurs with $200 \mathrm{nmol}$. $1^{-1}$ ATP, and around $40 \mu \mathrm{mol} \cdot 1^{-1}$ ATP for phosphorylation of the $86-$ and $23-\mathrm{kDa}$ proteins, indicating the operation of two distinct kinases. Guanosine-, uridine-, cytidine 5'-triphosphate and AMP are poor inhibitors of the labelling of the $64-\mathrm{kDa}$ protein with $\left[\gamma^{32} \mathrm{P}\right] \mathrm{ATP}$. On the other hand, ADP has a potent influence on the extent of labelling (half-maximal inhibition at $1-5 \mu \mathrm{mol}$. $1^{-1}$ ). The ADP-dependent appearance of ${ }^{32} \mathrm{P}$ in ATP indicates that ADP acts by reversal of kinase activity and not as a competitive inhibitor. However, the most rapid loss of ${ }^{32} \mathrm{P}$ from pre-labelled 64-kDa protein occurs when envelope vesicles are incubated with ATP $\mathrm{t}^{1 / 2}=15 \mathrm{~s}$ at $20 \mu \mathrm{mol} \cdot 1^{-1}$ ATP). This induced turnover of phosphate appears to be responsible for the rapid phosphoryl turnover seen in situ.
\end{abstract}

Key words: Chloroplast envelope - Phosphoprotein - Pisum (protein phosphorylation) - Protein kinase - Protein phosphorylation

Abbreviations: $\mathrm{LHCP} \quad \mathrm{II}=$ light-harvesting chlorophyll-a/bbinding protein $; \mathrm{S}_{0.5}=$ concentration giving half-maximal phosphorylation; SDS-PAGE = sodium dodecyl sulfate-polyacrylamide gel electrophoresis; Tricine $=\mathrm{N}-[2$-hydroxy-1,1-bis(hydroxymethyl)ethyl]glycine

\section{Introduction}

All members of the plastid family are surrounded by a pair of unit membranes, the inner and outer envelopes. The envelope membranes have specific enzymatic functions and control the flux of lowmolecular-weight substances and proteins in and out of the organelles (Douce et al. 1984). The two membranes are connected at some points (Carde et al. 1982; Cline et al. 1985) which are called contact sites, but these are not numerous. In general the gap between the two membranes is seen as an electron-translucent space with an average width of $6 \mathrm{~nm}$ (Carde et al. 1982).

The proteins localized in the lumen are on the one side in communication with the cytoplasm because they can be influenced by low-molecularweight substances which can pass through the pores of the outer envelope (Flügge and Benz 1984). On the other hand, these proteins are in contact with the outer leaflet of the inner envelope membrane and are the first to be influenced by metabolites transported out off the chloroplasts (Flügge and Heldt 1981).

The proteins of the intermembrane space between the outer and the inner envelope were inaccessable to study, because during the isolation of envelope membranes most of the soluble content of this chloroplast compartment is lost and recovered in the soluble chloroplast extract. This fraction however contains mostly soluble proteins of the stroma compartment, the soluble interenvelope proteins represent a minor portion of the total soluble protein. When envelope membranes are separated into inner and outer envelope membranes after a hypertonic sucrose treatment and mechanical lysis of the chloroplasts (Keegstra and Youssif 1986; Block et al. 1983) the soluble intermembrane 
content is completly lost and cannot be distinguished from stromal proteins. However, when chloroplasts are lysed in hypotonic buffer at least some of the intermembrane content is recovered in the fraction containing mixed envelope membranes, because inner and outer membranes may fuse during lysis along the breaking edges to yield a chimeric envelope vesicle which holds some soluble intermembrane content (Carde et al. 1982).

We have recently shown for pea chloroplasts that a $64-\mathrm{kDa}$ phosphoprotein is located in the interenvelope lumen, the first protein localized to that compartment (Soll and Bennett 1988). Evidence for this location was as followed: (i) specific labelling of the protein with $\left[\gamma_{-}{ }^{32} \mathrm{P}\right]$ ATP was higher in envelope vesicles derived from chloroplasts by hypotonic shock than in thylakoids or soluble protein extracts; (ii) the protein was released from such vesicles by sonication; (iii) the protein was not recovered with separated inner and outer envelopes generated from chloroplasts by hypertonic shock; (iv) when intact chloroplasts were incubated at $4^{\circ} \mathrm{C}$ to slow the entry of $\left[\gamma^{32} \mathrm{P}\right] \mathrm{ATP}$ into the organelles, the $64-\mathrm{kDa}$ protein was labelled before and more rapidly than the light-harvesting chlorophyll-a/b-binding protein (LHCP II) and two stromal marker proteins.

The kinase responsible for phosphorylating the $64-\mathrm{kDa}$ protein has not yet been identified but is presumably located either in the envelope lumen or on the the inner or outer envelope membrane. Since sonication or hypotonic shock releases both the $64-\mathrm{kDa}$ protein and its kinase from envelopes, the kinase is either soluble in the lumen or bound loosely to one of the envelope membranes. In intact chloroplasts, the kinase is able to use exogenous ATP which enters the lumen through pores in the outer envelope, or endogenous ATP which is generated within the chloroplast by photophosphorylation and is presumed to be transferred across the inner envelope membrane into the lumen by the adenylate translocator. Thus, ATP for phosphorylation of this protein in vivo could be derived from either the cytoplasm or the chloroplast. Since energy charge and adenylates are known to regulate many protein kinases, including the thylakoidbound kinase which phosphorylates LHCP II (Bennett 1977), we investigated the effects of ATP, ADP, AMP and other nucleotides on the phosphorylation of the $64-\mathrm{kDa}$ protein in envelope vesicles. The data show that the kinase of the $64-\mathrm{kDa}$ protein is exceptionally sensitive to the presence of ATP and ADP. Indeed, with the $\mathrm{S}_{0.5}$ (ATP) of its kinase estimated to be around $200 \mathrm{nmol} \cdot \mathrm{l}^{-1}$ and with a rapidly turned over phosphoryl group, the $64-\mathrm{kDa}$ protein may participate in an energydissipation cycle within the envelope lumen.

\section{Material and methods}

Pea plants (Pisum sativum L., cv. Golf, Bayrische Futtersaatbau, München, FRG) were grown on vermiculite in the greenhouse for two weeks. $\left[\gamma^{3}{ }^{32} \mathrm{P}\right] \mathrm{ATP}\left(110 \mathrm{TBq} \cdot \mathrm{mmol}^{-1}\right)$ was from Amersham Buchler, Braunschweig, FRG. All other chemicals were of reagent grade and used without further purification.

Isolation of chloroplasts and chloroplast subfractions. Chloroplasts were isolated in low-ionic-strength medium as described in (Nakatani and Barber 1977). The crude chloroplasts were further purified on a discontinous silica sol gradient (Mourioux and Douce 1981). Intact, purified chloroplasts were washed free of Percoll. The final pellet was resuspended in hypotonic (10 mmol-1 $1^{-1} \mathrm{~N}$-[2-hydroxy-1,1-bis(hydroxymethyl)ethyl]glycine (Tricine)- $\mathrm{KOH}, \mathrm{pH} \mathrm{7.9)}$ and chloroplasts lysed on ice for 5-10 min. A fraction containing mixed envelope membranes was obtained by a flotation centrifugation as described in (Cline et al. 1981). The lysed chloroplasts were brought to $39 \%$ sucrose by the addition of saturated sucrose solution. The suspension was overlayered by $3 \mathrm{ml}, 10 \mathrm{ml}$ and $10 \mathrm{ml}$ of $1.25,1.2$ and $0.3 \mathrm{~mol} \cdot \mathrm{l}^{-1}$ sucrose solution respectively, buffered with $10 \mathrm{mmol} \cdot \mathrm{1}^{-1}$ Tricine-KOH, $\mathrm{pH} 7.9$. Mixed membranes were recovered from the $1.2-0.3 \mathrm{~mol} \cdot 1^{-1}$ sucrose interphase after $3 \mathrm{~h}$ of centrifugation of $120000 \mathrm{~g}$.

Assay for protein phosphorylation and protein dephosphorylation. Phosphorylation of the $64-\mathrm{kDa}$ protein was assayed in general in $25 \mathrm{mmol} \cdot 1^{-1}$ Tricine-KOH, pH 7.9, $4 \mathrm{mmol} \cdot 1^{-1} \mathrm{MgCl}_{2}$, $5-10 \mu \mathrm{g}$ envelope protein and $33 \mathrm{nmol} \cdot 1^{-1}\left[\gamma^{32} \mathrm{P}\right] \mathrm{ATP}$ for $90 \mathrm{~s}$ in $25 \mu$ final volume at room temperature. The phosphorylation reaction was terminated by the addition of $25 \mu l$ of twofold-concentrated solubilisation buffer (Laemmli 1970). Protein dephosphorylation was assayed after mixed membranes were phosphorylated in the standard incubation mixture for $2 \mathrm{~min}$. Envelope membranes were centrifuged at $13000 \cdot \mathrm{g}$ for $2 \mathrm{~min}$, resuspended in $25 \mathrm{mmol} \cdot 1^{-1}$ Tricine-KOH, pH $7.9,4 \mathrm{mmol} \cdot 1^{-1}$ $\mathrm{MgCl}_{2}$ and dephosphorylation assayed in the presence or absence of ADP. Dephosphorylation was assayed for $10 \mathrm{~min}$ at room temperature in a final volume of $10 \mu \mathrm{l}$. The assay was either terminated by the addition of $25 \mu \mathrm{l}$ of twofold-concentrated solubilisation buffer (see above) or samples were fractionated into a membrane fraction and a supernatant by centrifugation at $13000 \cdot \mathrm{g}$ for $3 \mathrm{~min}$. Aliquots of the supernatant were spotted on precoated polyethylenimine-cellulose thin-layer chromatography plates (G 1440 PEI; Schleicher \& Schüll, Dassel, FRG) and nucleoside phosphates analysed using $1 \mathrm{~mol} \cdot \mathrm{1}^{-1}$ $\mathrm{KH}_{2} \mathrm{PO}_{4}$ as resolving buffer. Labelled ATP was identified by parallel chromatography of $\left[\gamma-{ }^{32} \mathrm{P}\right] \mathrm{ATP}$ from commercial sources.

Miscellaneous. Protein was determined as in (Lowry et al. 1951). Labelled proteins were analysed by sodium dodecyl sulfatepolyacrylamide gel electrophoresis (SDS-PAGE; Laemmli 1970) using a 10\% separating gel. Radioactivity in SDS-PAGE was quantified by excising the gel slices off the gel, rehydration by $0.5 \mathrm{ml}$ water and subsequent liquid scintillation counting. Autoradiography was done overnight at $-80^{\circ} \mathrm{C}$ using an intensifying screen (RP 1, MR-800 Agfa-Gevaert, Leverkusen, FRG).

\section{Results}

We have recently demonstrated that a $64-\mathrm{kDa}$ hydrophilic phosphoprotein resides in the lumen be- 


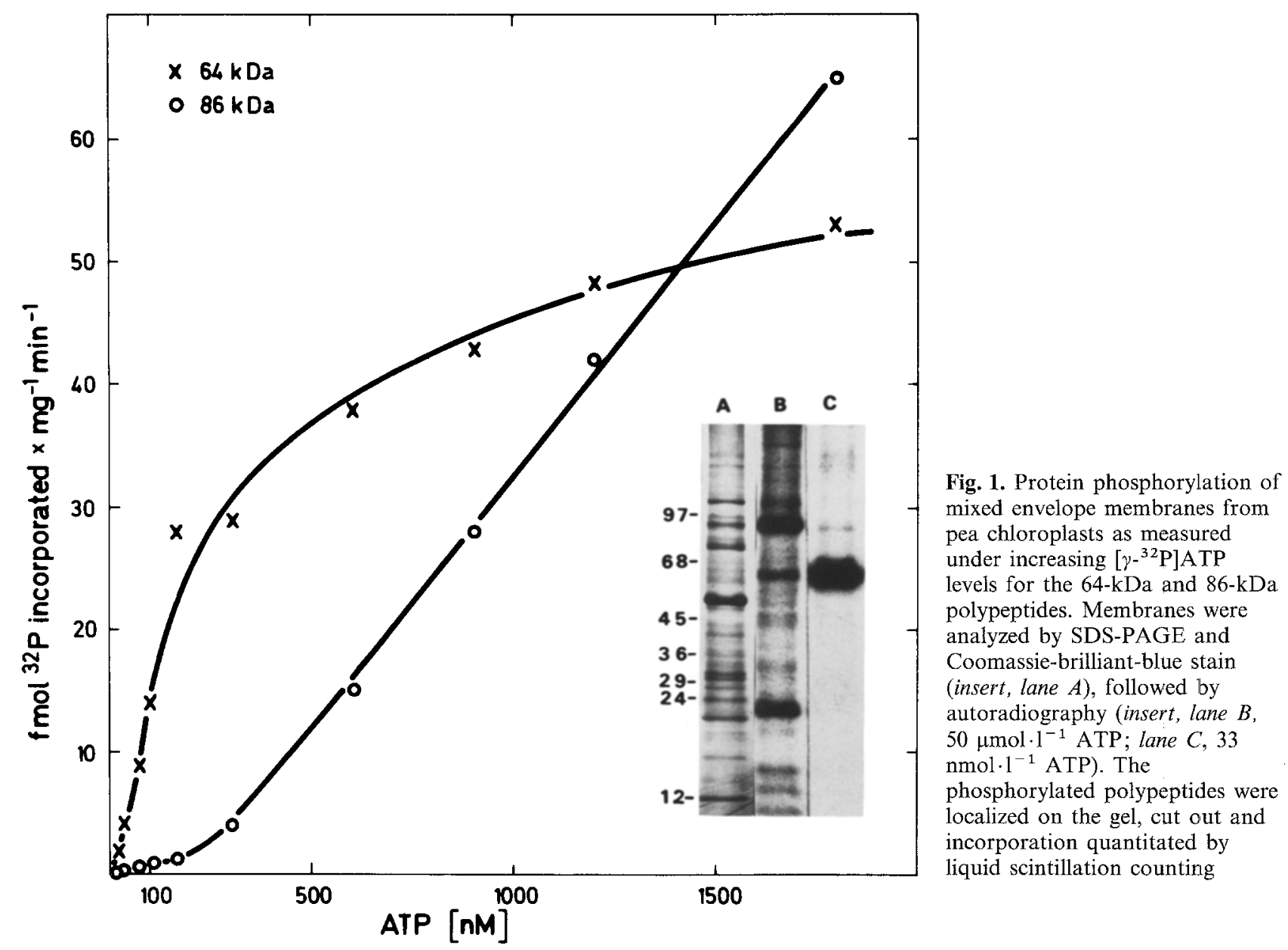

tween the inner and the outer envelopes from pea chloroplasts (Soll and Bennett 1988). Other phosphoproteins are bound to the envelope membranes, including two prominent outer-envelope proteins of 23 and $86 \mathrm{kDa}$. The phosphorylation pattern of mixed envelope membranes after a 1 -min incubation differs strikingly at low ATP $\left(33 \mathrm{nmol} \cdot 1^{-1}\right)$ and high ATP $\left(50 \mu \mathrm{mol} \cdot 1^{-1}\right)$ concentrations (insert Fig. 1). At $33 \mathrm{nmol} \cdot 1^{-1}$ ATP the $64-\mathrm{kDa}$ luminal protein is the polypeptide labelled most prominantly, while at $50 \mu \mathrm{mol} \cdot 1^{-1}$ ATP the $86-\mathrm{kDa}$ and $23-\mathrm{kDa}$ envelope proteins are the major phosphorylation products. The $64-\mathrm{kDa}$ protein is phosphorylated to the extent of $50 \%$ at a very low ATP concentration $\left(\mathrm{S}_{0.5} \approx 0.2 \mu \mathrm{mol} \cdot 1^{-1}\right.$, Fig. 1 ), while the other envelope phosphoproteins like the outerenvelope-bound 86- and 23-kDa phosphoproteins are labelled only at the higher ATP concentration $\left(\mathrm{S}_{0.5} \approx 37 \mu \mathrm{mol} \cdot 1^{-1}\right.$; Soll and Buchanan 1983).

The kinetics of envelope phosphorylation with $33 \mathrm{nmol} \cdot 1^{-1}$ ATP are shown in Fig. $2 .{ }^{32} \mathrm{P}$-Incorporation into the $64-\mathrm{kDa}$ protein from $\left[\gamma_{-}{ }^{32} \mathrm{P}\right] \mathrm{ATP}$ is linear only for about $60 \mathrm{~s}$ and labelling is complete after $3 \mathrm{~min}$. Upon addition of non-radioac- tive ATP $\left(20 \mu \mathrm{mol} \cdot \mathrm{l}^{-1}\right)$ the radioactive label present in the $64-\mathrm{kDa}$ protein decreases extremely rapidly. About $80 \%$ of the label is chased out within 30 s (Fig. 2), while the other phosphoproteins do not show such a behaviour (data not shown).

Incorporation of ${ }^{32} \mathrm{P}$ is strictly dependent on the presence of excess $\mathrm{Mg}^{2+}$. An optimal concentration is reached at $5 \mathrm{mmol} \cdot 1^{-1} \mathrm{Mg}^{2+}$, and $\mathrm{Mn}^{2+}$ cannot substitute for $\mathrm{Mg}^{2+}$ in its stimulatory effect. Phosphorylation of the 64-kDa protein is sensitive to changes in $\mathrm{pH}$ and to the kind of buffer used. A pH optimum of 7.9 is observed using Tricine-KOH (Fig. 3, insert). Phosphorylation is much slower in the acidic range, when bis(2-hydroxyethyl)iminotris(hydroxymethyl)methane is used. Buffers containing sulfonic-acid residues seem to be especially inhibitory of protein phosphorylation (Fig. 3, insert).

As expected from Fig. 1, cold ATP competes with $\left[\gamma^{32} \mathrm{P}\right] \mathrm{ATP}$ as phosphoryl donor in phosphorylation of the $64-\mathrm{kDa}$ protein (Table 1). In comparison, guanosine-, cytidine- and uridine 5'triphosphate (GTP, CTP, UTP) are much poorer competitors, indicating that these nucleoside tri- 


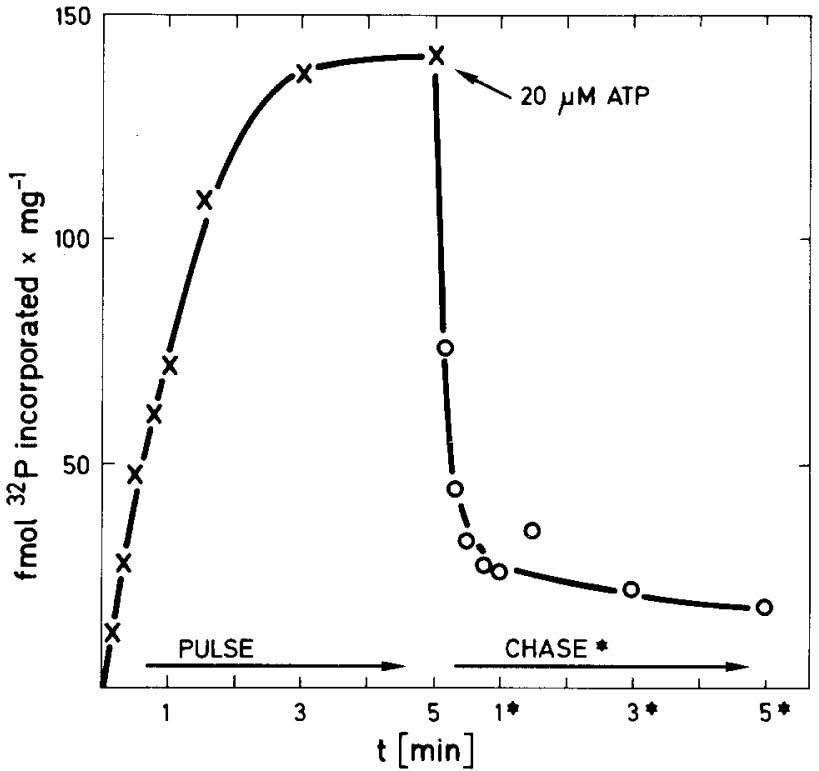

Fig. 2. Rapid phosphate turnover in the $64-\mathrm{kDa}$ protein from mixed envelope membranes of pea chloroplasts is demonstrated in a pulse-chase experiment. Aliquots were removed from the phosphorylation assay $\left(33 \mathrm{nmol} \cdot 1^{-1} \mathrm{ATP}\right)$ at the times indicated and the reaction terminated by solubilisation buffer. After a 5-min pulse, unlabelled ATP $\left(20 \mu \mathrm{mol} \cdot 1^{-1}\right)$ was added and aliquots removed from the chase and treated as above. Phosphorylation of the $64-\mathrm{kDa}$ protein was quantitated as described in Fig. 1

phosphates are probably not capable of acting as phosphoryl donors in the presence of ATP. We also measured the effect of AMP and ADP on phosphorylation of the $64-\mathrm{kDa}$ protein. Used in a thousandfold excess over ATP, AMP had no effect on the ATP-dependent phosphorylation (Table 1); ADP used in a concentration range between 3.3-330 nmol $\cdot 1^{-1}$ ADP (33 nmol $\cdot 1^{-1}\left[\gamma^{32}\right]$ ATP) was also without effect, indicating that ADP could not act as a competitive inhibitor (Fig. 4 insert). However, higher ADP levels (up to $33 \mu \mathrm{mol} \cdot 1^{-1}$ ) resulted in an almost complete disappearance of label in the $64-\mathrm{kDa}$ protein (data not shown). These results prompted us to look into different mechanisms whereby ADP could influence the phosphorylation status of the 64-kDa protein.

In general, two mechanisms exist to dephosphorylate a phosphoprotein (Edelman et al. 1987):

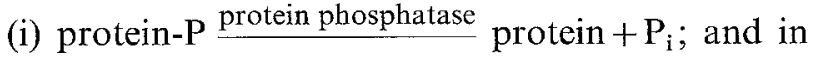

the case that a protein kinase works also in the reverse (ii) protein-P $+\mathrm{ADP} \leftrightharpoons$ protein $+\mathrm{ATP}$; this represents the reverse reaction of the protein or autophosphorylation reaction (Ehrlichmann et al. 1983). The reverse reaction has in general a much higher $\mathrm{K}_{\mathrm{m}}$ than the forward reaction. We tried to determine whether it was possible to detect ADP-

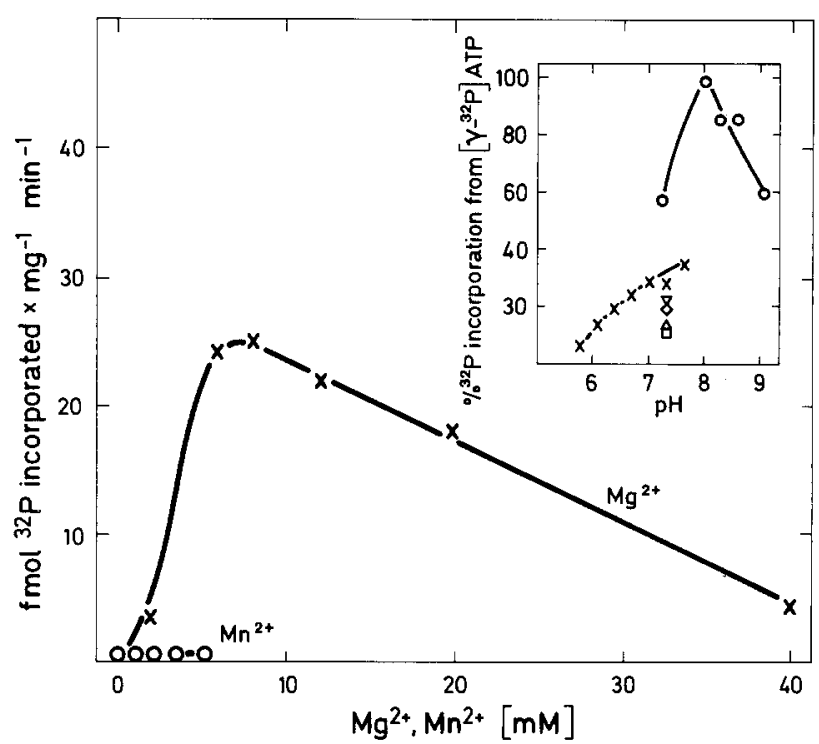

Fig. 3. Phosphate incorporation in the $64-\mathrm{kDa}$ protein from mixed envelope membranes of pea chloroplasts: influence of divalent cations $\mathrm{Mg}^{2+}, \mathrm{Mn}^{2+}$ and $\mathrm{pH}$ (insert). The effect of various buffers on the incorporation rate was determined at pH 7.2; Tricine- $\mathrm{KOH} \mathrm{(O-O),} \mathrm{bis(2-hydroxyethyl)imino-}$ tris(hydroxymethyl)methane $(x-x) . \quad \nabla=N-2$-hydroxyethylpiperazine- $\mathrm{N}^{\prime}$-2-ethane-sulfonic acid; $\diamond=$ morpholinopropane-sulfonic acid; $\Delta=$ piperazine-N,N'-bis[2-ethane-sulfonic acid]

Table 1. Phosphorylation of the $64-\mathrm{kDa}$ protein from mixed envelope membranes of pea chloroplasts was measured in the presence of various nucleoside-triphosphates and $\left[\gamma_{-}^{32} \mathrm{P}\right] \mathrm{ATP}$ $40 \mu \mathrm{mol} \cdot 1^{-1}$

\begin{tabular}{llllll}
\hline$\mu \mathrm{mol} \cdot 1^{-1}$ & \multicolumn{4}{l}{$\begin{array}{l}\text { Incorporation of }\left[\gamma^{32} \mathrm{P}\right] \text { ATP } \\
\left(\mathrm{fmol} \cdot \mathrm{mg}^{-1} \cdot \mathrm{min}^{-1}\right)\end{array}$} & in the presence of: \\
\cline { 2 - 6 } & AMP & GTP & CTP & UTP & ATP \\
\hline 0 & 4.44 & 4.44 & 4.44 & 4.44 & 4.44 \\
3.3 & 4.44 & 1.97 & 1.79 & 1.21 & 0.15 \\
10 & 4.44 & 1.21 & 0.79 & 0.4 & 0.05 \\
33 & 4.44 & 0.6 & 0.67 & 0.3 & 0.015 \\
\hline
\end{tabular}

dependent dephosphorylation. Mixed envelope membranes were phosphorylated for 2 min under standard conditions using $33 \mathrm{nmol} \cdot 1^{-1}[\gamma-$ ${ }^{32}$ P]ATP. Membranes were then recovered by centrifugation and incubated a second time in the presence or absence of ADP (Fig. 4). The synthesis of $\left[\gamma^{32} \mathrm{P}\right] \mathrm{ATP}$ was monitored by thin-layer chromatography on polyethylenimine-cellulose plates (Fig. 5). The ADP concentration needed for halfmaximal dephosphorylation is around $0.2 \mu \mathrm{mol}$. $1^{-1}$ (Fig. 4). Other membrane-bound phosphoproteins, like the $86-\mathrm{kDa}$ protein do not show ADP-dependent dephosphorylation (data not 


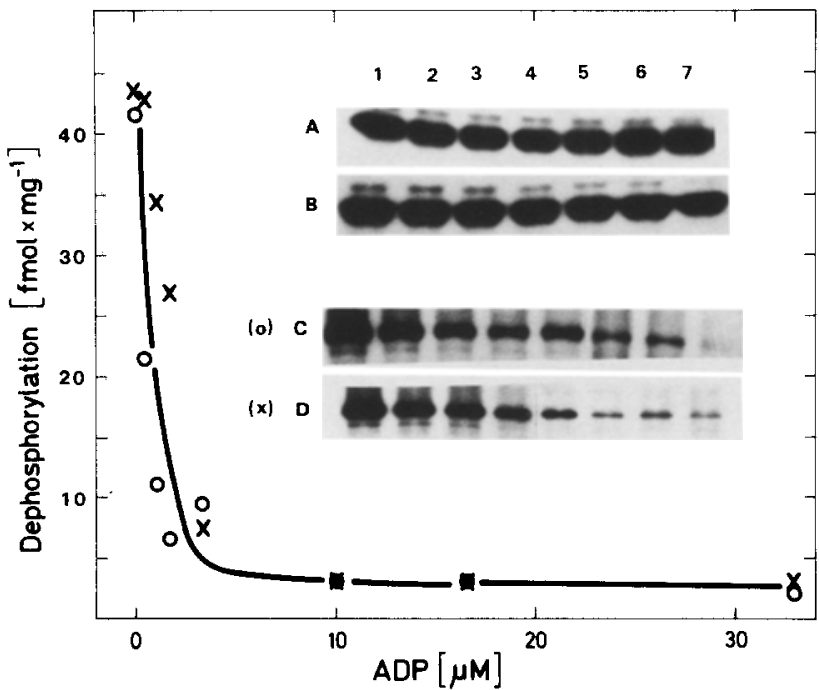

Fig. 4. The ADP-dependent dephosphorylation of the 64-kDa phosphoprotein from mixed envelope membranes of pea chloroplast. Mixed envelope membranes were labelled by $\left[\gamma_{-}{ }^{32} \mathrm{P}\right]$ ATP for $3 \mathrm{~min}$, membranes were recovered by centrifugation, the supernatant removed and the membranes incubated a second time in the presence of the indicated amounts of ADP. Phosphorylation with $\left[\gamma^{32} \mathrm{P}\right] \mathrm{ATP}$ was carried out at $40(\times)$ and 240 (O) $\mathrm{nmol} \cdot \mathrm{1}^{-1}$ ATP; respectively. Dephosphorylation assays were incubated for $10 \mathrm{~min}$. The inserts show autoradiograms of the dephosphorylation reaction as analyzed by SDSPAGE. Insert $C$ and $D$ correspond to the experiments shown in the graph. Insert $A$ and $B$ demonstrate the effect of ADP if it is simultaneously present together with $\left[\gamma^{3}{ }^{32} \mathrm{P}\right] \mathrm{ATP}$ (33 nmol.1 $1^{-1}$ ) in the phosphorylation assay; ADP (nmol.1 $1^{-1}$ ] insert $A$ lane $1-7,0,3.3,6.6,13,20,25,33$; insert $B$, lane $1-7,0,33,66,130,200,250,330$, respectively

shown). Newly synthesized $\left[\gamma^{32}\right.$ P]ATP was detectable only in experiments which contained ADP in the dephosphorylation assay (Fig. 5). Without exogenous ADP the label was fairly stable in the 64-kDa protein, while $50 \%$ dephosphorylation was reached after $3 \mathrm{~min}$ in the presence of ADP (Fig. 6). The ADP-dependent dephosphorylation was complete within $10 \mathrm{~min}$. The slower kinetics of ADP-dependent dephosphorylation clearly distinguishes this reaction from the very rapid ATPdependent chase experiment (Fig. 2).

Sodium fluoride (NaF), a known phosphatase inhibitor, had little influence on the ADP-dependent dephosphorylation (Fig. 7, insert). Quantitation of the results shown in Fig. 7 demonstrated that only about $10 \%$ of the total dephosphorylation measured was the consequence of ADP-independent dephosphorylation either by a protein phosphatase or an unspecific dephosphorylation reaction. Dephosphorylation depends specifically on ADP and cannot be replaced by other nucleoside diphosphates like GDP or UDP (Fig. 7).

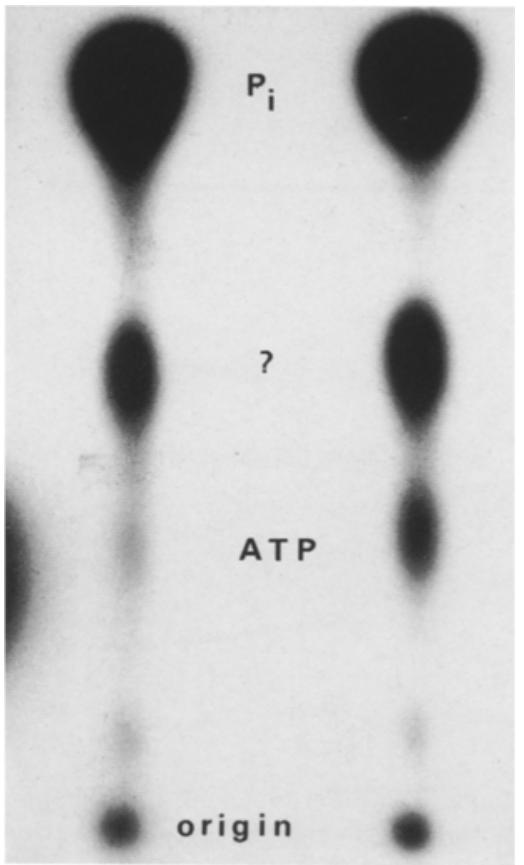

Fig. 5. The ADP-dependent dephosphorylation of the 64-kDa phosphoprotein from mixed envelope membranes of pea chloroplasts yields $\left[\gamma^{32} \mathrm{P}\right] \mathrm{ATP}$. Prelabelled mixed envelope membranes (compare (Fig. 4) were incubated in the absence or presence of $20 \mu \mathrm{mol} \cdot 1^{-1}$ ADP for $10 \mathrm{~min}$. One $\mu \mathrm{l}$ of the supernatant obtained by centrifugation at $13000 \cdot \mathrm{g}$ for $3 \mathrm{~min}$ was spotted on polyethylenimine-cellulose plates and developed in $1 \mathrm{~mol}$. $1^{-1} \mathrm{KH}_{2} \mathrm{PO}_{4}$. The autoradiogram is shown. The left lane shows the control experiment without added ADP, the result shown in the right lane was obtained in the presence of $20 \mu \mathrm{mol} \cdot \mathrm{I}^{-1}$ $\mathrm{ADP}$

The ADP-dependent dephosphorylation of the $64-\mathrm{kDa}$ protein is stimulated by $\mathrm{Mg}^{2+}$. No dephosphorylation is observed in the presence of 1 mmol $\cdot 1^{-1}$ ethylene diaminetetraacetic acid (EDTA), $1 \mathrm{mmol} \cdot \mathrm{l}^{-1} \mathrm{Mg}^{2+}$ and $20 \mu \mathrm{mol} \cdot \mathrm{l}^{-1}$ ADP, while half-maximal dephosphorylation was observed at about $2 \mathrm{mmol} \cdot 1^{-1} \mathrm{Mg}^{2+}$ in excess of added EDTA (data not shown). The ADP-dependent dephosphorylation had a broad optimal $\mathrm{pH}$ range between $\mathrm{pH} 7.0-9.0$; in general all assays were done at $\mathrm{pH}$ 7.9. We still observed $50 \%$ ADPdependent dephosphorylation at $\mathrm{pH} 6.0$.

\section{Discussion}

The present study characterizes the phosphorylation and dephosphorylation of a $64-\mathrm{kDa}$ protein which exhibits very interesting labelling behaviour with respect to the kinetics of the reaction and its regulation by adenylate. Radioactive phosphate incorporated into the $64-\mathrm{kDa}$ envelope protein is stable for at least $10 \mathrm{~min}$ in the absence of either 


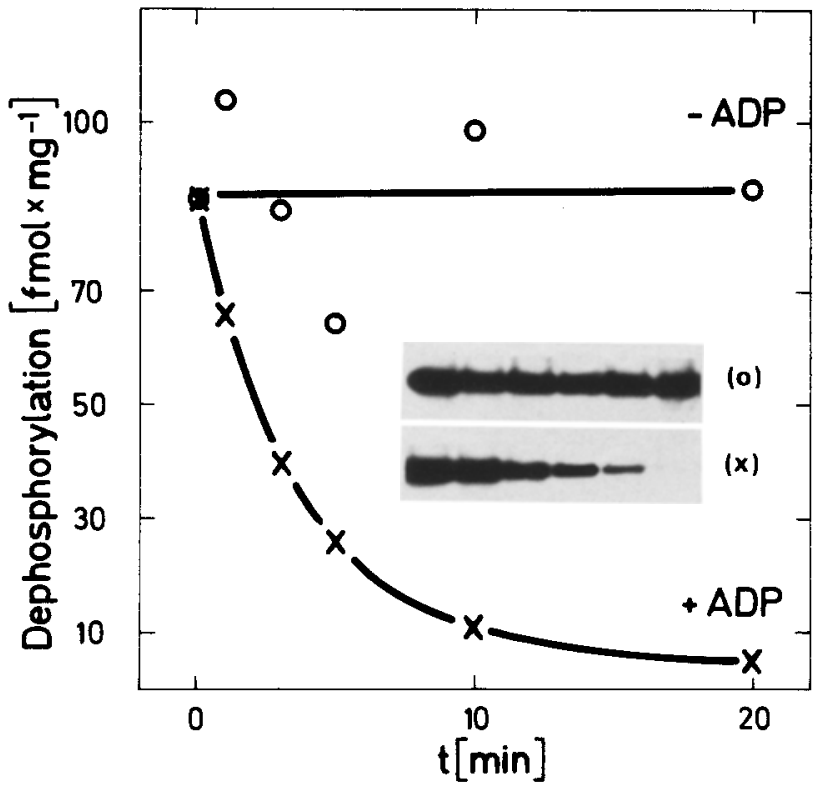

Fig. 6. Dephosphorylation of the 64-kDa protein from pea chloroplasts occurs in a time- and ADP-dependent manner. Mixed envelope membranes were phosphorylated for $2 \mathrm{~min}$ at 33 nmol $\cdot 1^{-1}\left[\gamma^{32} \mathrm{P}\right]$ ATP and dephosphorylated as described in Material and methods using $20 \mu \mathrm{mol} \cdot \mathrm{l}^{-1} \mathrm{ADP}$. The insert shows the autoradiogram of SDS-PAGE which was used to quantify the data by liquid scintillation counting

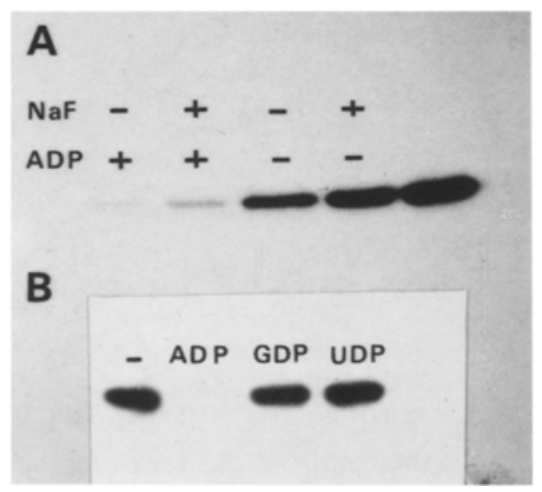

Fig. 7 A, B. The ADP-dependent dephosphorylation of the 64$\mathrm{kDa}$ protein from pea chloroplasts (A) is measured in the presence or absence of ADP $\left(20 \mu \mathrm{mol} \cdot 1^{-1}\right)$ and the phosphatase inhibitor $\mathrm{NaF}\left(50 \mathrm{mmol} \cdot \mathrm{1}^{-1}\right)$. Mixed envelope membranes were phosphorylated for $90 \mathrm{~s}$ (right lane), then dephosphorylation was assayed as in Material and methods using $20 \mu \mathrm{mol} \cdot 1^{-1}$ ADP. (B) Dephosphorylation of the $64-\mathrm{kDa}$ protein depends on ADP and cannot be replaced by GDP or UDP $(20 \mu \mathrm{mol}$ $1^{-1}$ ). All other conditions as in Material and methods

ATP or ADP. However, addition of either of these molecules to pre-labelled envelope membranes leads to the rapid loss of ${ }^{32} \mathrm{P}$ from this protein. The half-time for ADP-dependent loss is about $3 \mathrm{~min}$, while that for ATP-dependent loss is about $15 \mathrm{~s}$. The mechanism of the ADP-dependent loss of radioactivity from the protein seems clear: the recovery of radioactive ATP indicates that the protein kinase responsible for phosphorylating the 64$\mathrm{kDa}$ protein has been forced to operate in reverse. The cyclic-AMP-dependent kinase of animal cells has been shown to exhibit similar behaviour, both with respect to autophosphorylation and phosphorylation of histone (Rosen and Ehrlichman 1975). In contrast, the ATP-dependent removal of ${ }^{32} \mathrm{P}$ from the $64-\mathrm{kDa}$ protein poses mechanistic problems which remain to be resolved. We have not yet identified the acceptor of the phosphoryl group derived from the $64-\mathrm{kDa}$ protein; it does not appear to be transferred to another protein. The fact that the ATP-dependent-event removal of ${ }^{32} \mathrm{P}$ is faster than the ADP-dependent event indicates that a different mechanism is involved.

The ATP concentration giving half-maximal phosphorylation $\left(\mathrm{S}_{0.5}\right)$ of the $64-\mathrm{kDa}$ luminal protein is very low (about $200 \mathrm{nmol} \cdot 1^{-1}$ ). It is unlikely that the ATP concentration in vivo would ever be sufficiently low to limit the rate of this enzymatic phosphorylation. The ability of ADP to reverse the reaction could form a basis for regulation but probably only at high ADP/ATP ratios. Nothing is known about the adenylate ratios of the envelope lumen. One major stabilizing factor on the ADP/ ATP ratio is the equilibrium among AMP, ADP and ATP established by adenylate kinase. The chloroplast stroma contains at least half the adenylate kinase of cells and the adenylate pool of the stroma has been shown to be subject to rigid adenylate-kinase equilibrium. The remainder of the adenylate kinase of the leaf is thought to be localized in mitochondria, probably in the space between the inner and outer membranes. However, it remains possible that some adenylate-kinase activity might reside in the envelope lumen (Murakami and Strotmann 1978). If so, then it is unlikely that sufficiently high ADP/ATP ratios could be generated to reverse the phosphorylation of the 64-kDa protein.

The $S_{0.5}$ (ATP) for phosphorylation of the 64$\mathrm{kDa}$ protein is also low compared with other protein-kinase reactions of the chloroplast. Thus the corresponding $\mathrm{S}_{0.5}$ (ATP) for the phosphorylation of the $86-\mathrm{kDa}$ outer-envelope protein is about 37 $\mu \mathrm{mol} \cdot 1^{-1}$ (Soll and Buchanan 1983; Soll 1985) and the $K_{\mathrm{m}}$ (ATP) for phosphorylation of LHCP II in the thylakoids has been reported to be variously $25 \mu \mathrm{mol} \cdot 1^{-1}$ or $90 \mu \mathrm{mol} \cdot 1^{-1}$. Autophosphorylation of LHCP II kinase exhibits a $\mathrm{K}_{\mathrm{m}}$ (ATP) of $25 \mu \mathrm{mol} \cdot 1^{-1}$ (Coughlan and Hind 1987).

The ability of non-radioactive ATP to chase radioactive phosphate out of the $64-\mathrm{kDa}$ protein 
indicates that the phosphoryl group of this protein undergoes constant turnover. We measure a maximum turnover rate of about 100 fmol phosphate. (mg envelope protein) $)^{-1} \cdot \mathrm{min}^{-1}$, and even if $90 \%$ of the activity has been lost during envelope isolation, a corrected turnover rate of $1 \mathrm{pmol}$. (mg envelope protein $)^{-1} \cdot \min ^{-1}$ would not represent an appreciable drain on the ATP supply of the cell. It would also not be limited by the rate of translocation of ATP out of the chloroplasts, a process which has a maximum velocity of about $4 \mu \mathrm{mol}$. (mg chlorophyl) ${ }^{-1} \cdot \mathrm{h}^{-1}$ (or about $70 \mathrm{nmol}$ ATP. (mg envelope protein $)^{-1} \cdot \min ^{-1}$, assuming that envelopes constitute $1 \%$ of total plastid protein and that the protein to chlorophyll ratio of plastids is 10/1; Douce et al. 1984). The velocity of import of the small subunit of ribulose-1,5-bisphosphate carboxylase (Rubisco) into chloroplasts is about $35 \mathrm{pmol} \cdot(\mathrm{mg} \text { chlorophyll })^{-1} \cdot \mathrm{h}^{-1}$, or about 60 fmol $\cdot(\mathrm{mg} \text { envelope protein })^{-1} \cdot \mathrm{min}^{-1}$, which is of the same order as the rate of 64-kDa phosphorylgroup turnover (Schindler et al. 1987).

To explain the relevance of the ATP-dependent turnover of the phosphoryl group of the 64-kDa protein we will need to discover the role of this protein within the envelope lumen. Although protein phosphorylation/dephosphorylation has been implicated in the transport of proteins into the chloroplast (Schindler et al. 1987), there are at present no data to implicate either the $64-\mathrm{kDa}$ protein or any of the inner- and outer-envelope phosphoproteins in the transport process. We believe that a careful characterization of the envelope phosphoproteins and their kinases will play an important role in revealing the structure, organization and regulation of envelope proteins.

As already mentioned, most of the soluble content of the interenvelope lumen is lost during the isolation and recovered together with soluble proteins of the chloroplast stroma. Today we have no reliable data showing how much of the lumen content is actually lost. We have demonstrated earlier (Soll and Bennett 1988) that the 64-kDa protein detected in the mixed envelope fraction and the soluble-chloroplast-protein fraction are identical. Care should be taken not to confuse stromal proteins and soluble proteins from chloroplasts. In this light, reports which document a "stromal" phosphoprotein of $67-\mathrm{kDa}$ from spinach chloroplasts (Cortez et al. 1987; Guitton and Mache 1987) must be taken cautiously, since their experiments were carried out with total soluble chloroplast extract, making it likely that the phosphoprotein described by them and in our study are most probably identical (data not shown).
This work was supported by the Deutsche Forschungsgemeinschaft. The work at the Brookhaven National Laboratory was carried out under the auspicies of the US Department of Energy and with the funding from its office of Basic Energy Sciences, Division of Biological Energy Research.

Note added in proof: Hinz and Flügge (1988, Eur. J. Biochem. $\mathbf{1 7 5}, 649-659$ ) have reported that phosphorylation of a $51-\mathrm{kDa}$ outer-chloroplast-envelope protein is involved in protein translocation into spinach chloroplasts.

\section{References}

Bennett, J. (1977) Chloroplast protein phosphorylation couples plastoquinone redox state to distribution of excitation energy between photosystems. Nature 269, 344-346

Block, M.A., Dorne, A.J., Joyard, J., Douce, R. (1983) Preparation and characterization of membrane fractions enriched in outer and inner envelope membranes from spinach chloroplasts. J. Biol. Chem. 258, 13273-13286

Carde, J.P., Joyard, J., Douce, R. (1982) Electron microscopic studies of envelope membranes from spinach plastids. Biol. Cell 44, 315-324

Coughlan, S.J., Hind, G. (1987) Phosphorylation of thylakoid proteins by a purified kinase. J. Biol. Chem 262, 8402-8408

Cline, K., Andrews, J., Mersey, B., Newcomb, B.H., Keegstra, K. (1981) Separation and characterization of inner and outer envelope membranes of pea chloroplasts. Proc. Natl. Acad. Sci. USA 78, 3595-3599

Cline, K., Keegstra, K., Staehelin, L.A. (1985) Freeze-fracture electron microscopic analysis of ultrarapidly frozen envelope membranes on intact chloroplasts and after purification. Protoplasma 125, 111-113

Cortez, M., Lucero, H.A., Vallejos, R.H. (1987) Stromal serine protein kinase activity in spinach chloroplastș. Arch. Biochem. Biophys. 254, 504-508

Douce, R., Block, M.A., Dorne, A.J., Joyard, J. (1984) The plastid envelope membranes; their structure, composition and role in chloroplast biogenesis. Subcell. Biochem. 10, $1-84$

Edelman, A.M., Blumenthal, O.K., Krebs, E.G. (1987) Protein serine/theorine kinases. Annu. Rev. Biochem. 56, 567-613

Ehrlichman, J., Rangel-Aldao, R., Rosen, O.A. (1983) Reversible autophosphorylation of type II cAMP-dependent protein kinase: distinction between intramolecular and intermolecular reactions. Methods Enzymol. 99, 176-186

Flügge, U.J., Benz, R. (1984) Pore-forming activity in the outer membrane of the chloroplast envelope. FEBS Lett. 169, 8589

Flügge, U.J., Heldt, H.W. (1981) The phosphate translocator of the chloroplast envelope: isolation of the carrier protein and reconstitution of transport. Biochim. Biophys. Acta 638, 296-304

Guitton, C., Mache, R. (1987) Phosphorylation in vitro of the large subunit of the ribulose-1,5-bisphosphate carboxylase and of the glutaraldehyde-3-phosphate dehydrogenase. Eur. J. Biochem. 166, 249-254

Keegstra, K., Youssif, A.E. (1986) Isolation and characterization of chloroplast envelope membranes. Methods Enzymol. 118, 316-325

Laemmli, U.K. (1970) Cleavage of structural proteins during the assembly of the heads of bacteriophage T4. Nature 227, 680-685

Lowry, O.H., Rosebrough, N.J., Farr, A.L., Randall, R.J. (1951) Protein measurement with the folin phenol reagent. J. Biol. Chem. 193, 265-275 
Mourioux, G., Douce, R. (1981) Slow passive diffusion of orthophosphate between isolated chloroplasts and suspending medium. Plant. Physiol. 67, 470-473

Murakami, S., Strotmann, H. (1978) Adenylate kinase bound to the envelope membranes of spinach chloroplasts. Arch. Biochem. Biophys. 185, 30-38

Nakatani, H.J., Barber, J. (1977) An improved method for isolating chloroplasts retaining their outer membranes. Biochim. Biophys. Acta 416, 510-512

Rosen, O.M., Ehrlichman, I. (1975) Reversible autophosphorylation of a cyclic- $3^{\prime}: 5^{\prime}$-AMP-dependent protein kinase from bovine cardiac muscle. J. Biol. Chem. 250, 7788-7794

Schindler, C., Hracky, R., Soll, J. (1987) Protein transport in chloroplasts: ATP is prerequisit. Z. Naturforsch. 42c, 103108

Soll, J. (1985) Phosphoproteins and protein kinase activity in isolated envelopes of pea chloroplasts. Planta 166, 394-400

Soll, J., Bennett, J. (1988) Localization of a 64-kDa phosphoprotein in the lumen between the inner and outer envelopes of pea chloroplasts. Eur. J. Biochem. 175, 301-307

Soll, J., Buchanan, B.B. (1983) Phosphorylation of chloroplast ribulose biphosphate carboxylase-oxygenase small subunit by an envelope bound protein kinase in situ. J. Biol. Chem. 258, 66866689

Received 8 August; accepted 20 October 1988 